\title{
Effects of substantia nigra lesions on the volumes of $A, B$, and $D$ cells and the content of insulin and glucagon in the rat pancreas
}

\author{
B.J. Davis* and P.H.Smith \\ Department of Anatomy and Cell Biology, Upstate Medical Center, State University of New York, Syracuse, New York, USA
}

\begin{abstract}
Summary. The effects of substantia nigra lesions on the volume densities of islet cells and on the content of insulin and glucagon in the pancreas were examined using five groups of age-matched, Sprague-Dawley rats. Two groups received bilateral substantia nigra lesions using intrathecal injections of either a low $(6 \mu \mathrm{g} / \mathrm{hemisphere})$ or a high $(12 \mu \mathrm{g} / \mathrm{hemisphere})$ dose of 6-hydroxydopamine. Rats given sham lesions served as controls for the effects of the neurotoxic drug. These three groups, plus a fourth consisting of unoperated controls, were provided with a high-fat diet to minimize lesion-induced alterations of food intake and body weight. Eleven weeks after lesion placement, tissue was collected from all animals for the assessment of islet cell volume densities and the pancreatic content of insulin and glucagon. Plasma samples also were obtained to determine the levels of glucose, insulin, and glucagon. Data from those animals were compared with that obtained from a fifth group, termed "pre-lesion controls", sacrificed at the beginning of the experiment. Linear-scan mor-
\end{abstract}

phometry documented an increase of B-cell volume density in the pancreas of non-lesioned rats over the 11-week period $(p<0.05)$. However, the volume density of B cells in the pancreas of lesioned animals did not increase compared with that of pre-lesion controls. In terms of A or D cells, no significant differences of volume density were found between the five groups. Compared with that of the pre-lesion controls, pancreatic insulin and glucagon content increased in the lesioned and neurally-intact animals. However, the molar ratio of those hormones in the pancreas of lesioned rats remained similar to that of pre-lesion controls. The current findings suggest that the substantia nigra is an important autonomic area involved in controlling islet growth and development, and possibly islet function as well.

Key words: Pancreatic islets, substantia nigra, rat, autonomic nervous system, neural control.
Control of pancreatic islet function by the autonomic nervous system is now amply documented [1, 2]. Stimulation or sectioning of pancreatic nerves predictably alters the secretion of hormones from all major islet cell types [1, 2]. Within the central nervous system, experimental manipulation of the ventromedial or ventrolateral hypothalamus results in classical effects upon food intake and body weight $[3,4]$, promotes significant alterations of islet hormone release [5-8], and alters islet morphology $[9,10]$.

In addition to the ventral hypothalamus, several other central nervous system areas may be involved in modulating autonomic signals reaching the islets. The substantia nigra (SN), for example, is a mesencephalic region that has been implicated in the regulation of food intake and body weight $[11,12]$. Recently, we reported [13] that chemical lesions of the $\mathrm{SN}$ in rats were

\footnotetext{
* Present address: Department of Neurology, University of Rochester School of Medicine and Dentistry, Rochester, NY, USA 14642
}

associated with reductions of both the size and volume density of their pancreatic islets. Because the volume density of islet tissue in $\mathrm{SN}$-lesioned rats was comparable to that of younger control animals, damage to this brain area appeared to have interrupted the expected rate of pancreatic islet growth. In this study we report additional data from those experiments concerning immunocytochemical identification of the islet cells contributing to the SN lesion-related reduction of islet growth, and how such lesions affected hormone levels in the plasma and pancreas.

\section{Materials and methods}

\section{Animals and housing}

Age-matched, male Sprague-Dawley rats weighing approximately $200 \mathrm{~g}$ were obtained from Taconic Farms, Germantown, New York, USA. Rats were housed individually in wire mesh cages with lights on from 06.00 to $18.00 \mathrm{~h}$. Prior to experimental use, all animals were allowed access to powdered Purina Laboratory Chow (Ralston-Purina, 
St. Louis, Missouri, USA) from 09.00 to $16.00 \mathrm{~h}$; water was available ad libitum. As reported earlier [13], when the rats attained body weights of approximately $340 \mathrm{~g}$ they were divided randomly into five experimental groups:

Group 1: Pre-lesion rats $(n=7)$ were killed by decapitation and pancreatic tissues were collected for morphometric studies and hormone assays as described below.

Group 2: Unoperated controls $(n=8)$ did not receive lesions, but were treated identically to groups $3-5$ below.

Group 3: Sham-lesioned rats $(n=7)$, given bilateral injections of a $0,2 \% \mathrm{NaCl}$-ascorbic acid vehicle solution (Sigma Chemical Co. St. Louis, Missouri) into the $\mathrm{SN}$ at a dose of $3.0 \mu \mathrm{l} / \mathrm{hemisphere,} \mathrm{were}$ treated identically to the lesioned rats (see below).

Group 4: Low-dose lesioned rats $(n=10)$ were given bilateral intranigral injections of the catecholamine neurotoxin [14], 6-hydroxydopamine (6-OHDA, Sigma), at a dose of $6 \mu \mathrm{g} / \mathrm{hemisphere.}$

Group 5: High-dose lesioned rats $(n=7)$ were given bilateral intranigral injections of $12 \mu \mathrm{g} /$ hemisphere of 6-OHDA.

\section{Lesions and post-operative care}

Following an overnight fast, rats were anaesthetised with ether and placed in a stereotaxic instrument (David Kopf Instruments, Tujunga, California, USA). Injections of 6-OHDA or vehicle were delivered bilaterally into the SN as described previously [13]. To block the uptake of 6-OHDA into noradrenergic neurons, all animals were injected with $20 \mathrm{mg} / \mathrm{kg}$ des-methylimipramine (USV Pharmaceuticals, Tarrytown, New York) $20 \mathrm{~min}$ prior to surgery [15]. Because desmethylimipramine apparently decreases gastric motility [16], food was withheld from all rats for 3 days following lesion placement. Water intake was recorded daily during the first post-operative week. Any rat not drinking at least $5 \mathrm{ml} /$ day was given $10 \mathrm{ml}$ of warmed tap water intragastrically. From day 4 following surgery until the conclusion of the experiment, all rats were allowed free access to a diet consisting of a 2:1 mixture (wt/wt) of powdered Purina Laboratory Chow and vegetable shortening (Crisco, Procter \& Gamble, Cincinnati, Ohio, USA) from 09.00 to $16.00 \mathrm{~h}$. This diet and feeding schedule was shown previously to minimise differences of body weight between the lesioned and control groups [13]. Body weight was recorded at weekly intervals until the conclusion of the experiment at 11 weeks following lesion placement.

\section{Tissue collection and processing}

Rats were killed by decapitation after an overnight fast. Brains were dissected and blocks of tissue containing the mesencephalon were processed for lesion verification using a fluorescence histochemical method [13]. Trunk blood was collected into chilled, heparinized centrifuge tubes containing $0.05 \mathrm{~mol} / 1$ benzamidine-HCl (Sigma) and aprotinin $(500 \mathrm{KIU} / \mathrm{ml}$, Trasylol, Sigma) to inhibit proteolytic degredation of hormones. Plasma was stored at $-20^{\circ} \mathrm{C}$ until assayed. The entire pancreas was dissected free from surrounding connective tissue and weighed. Tissue blocks of approximately $4 \mathrm{~mm}^{3}$ were dissected from the gastric, splenic, and duodenal regions. One set of tissues was weighed and homogenized in $2 \mathrm{ml}$ of acidified ethanol. Following an overnight extraction and centrifugation at $3000 \mathrm{~g}$ for $60 \mathrm{~min}$ the supernatant was stored at $-20^{\circ} \mathrm{C}$ until assayed for pancreatic hormones. A second set of tissues was weighed, fixed in Bouin's solution for $12 \mathrm{~h}$, then dehydrated in graded alcohols. Tissues from each animal were embedded in a single paraffin block to eliminate variability in the morphometric analyses due to regional differences of islet cytoarchitecture [17]. Sets of serial $4 \mu \mathrm{m}$ sections were obtained at $200-\mu \mathrm{m}$ intervals through the entire tissue block. Sections were mounted onto gelatin-coated glass slides and stored until stained.

\section{Immunocytochemistry}

Serial sections of pancreas were stained for the immunocytochemical localization of A (glucagon), B (insulin), and D (somatostatin) cells according to previously reported techniques $[13,18]$. The primary hor- mone antisera used were: rabbit anti-glucagon (1:500, antiserum 14D, a gift from Dr. R. C. McEvoy, Mount Sinai School of Medicine, New York; guinea-pig anti-insulin $(1: 100$, Cappel Laboratories, West Chester, Pennsylvania); or rabbit anti-somatostatin $(1: 1000$, a gift from Dr. J. W. Ensinck, University of Washington School of Medicine, Seattle, Washington). Control procedures included the use of sections incubated with an antiserum previously absorbed with an excess $(1-10 \mu \mathrm{g} / \mathrm{ml})$ of its appropriate antigen and normal serum used in place of an immune serum [18].

\section{Morphometric methods}

Initially, point-counting was used to determine the volume density of islet tissue by directly observing pancreatic sections under a microscope [19]. Then a linear intercept method was employed for determining volume densities of the A, B, and D cells [20]. In this latter method we used a Leitz Orthoplan microscope (Ernst Leitz, Wetzlar, FRG) with optical linear-encoders (Teledyne-Gurley, Troy, New York) attached to its stage. The linear-encoders measured distances along the $\mathrm{X}$ - and $\mathrm{Y}$-axes, and each was interfaced to a PDP-11/34 computer (Digital Equipment Corporation, Maynard, Massachusetts). Adjacent immunocytochemically-stained sections were scanned for both hormone-positive and unstained islet cells in at least 50 islets/pancreas. At a magnification of $X 430$, islets were scanned along their entire $\mathrm{X}$-axis at $50 \mu \mathrm{m}$ intervals of the $\mathrm{Y}$-axis. By this method, the volume density (Vd) of A, B, or D cells in the pancreas (Vd cell/pancreas) was individually quantitated based on the formula:

$$
\begin{aligned}
V d= & \frac{m m \text { of scan over a given cell type }}{\text { total } \mathrm{mm} \text { of scan over the islets }} \times \frac{\text { volume density of islets in }}{\text { the pancreas }} \\
= & V d(\text { cell } / \text { islet }) \times V d \text { (islet } / \text { pancreas) } \\
& \text { where } \mathrm{Vd}(\text { cell } / \text { islet })=\frac{\mathrm{mm} \mathrm{scan} \mathrm{cell} \mathrm{type}}{\mathrm{mm} \mathrm{scan} \mathrm{total} \mathrm{islet}}
\end{aligned}
$$

and

$$
\mathrm{Vd} \text { (islet/pancreas) }=\frac{\text { number of points islets }{ }^{1}}{\text { number of points islets plus exocrine }}
$$

The linear scan method also was used to verify our previous data on islet volume of the pancreas obtained via point-counting [13]. Both methods gave comparable results: by point-counting mean islet $\mathrm{Vd}=0.88 \%$, and by linear scan mean islet $\mathrm{Vd}=0.87 \%(n=8, r=0.93$, $p<0.001)$. As stated previously [13] at least 30000 points $\left(187.5 \mathrm{~mm}^{2}\right.$ tissue section) was analyzed per pancreas. This corresponds to approximately $1.5 \mathrm{~m}$ of linear scan per pancreas to give an estimated error [19] of $4 \%$.

The relative percentages of $\mathrm{A}, \mathrm{B}$, and $\mathrm{D}$ cells within individual islets were determined by counting the number of hormone-positive and non-positive cells with visible nuclei on adjacent immunostained sections of at least 50 islets per pancreas.

\section{Chemical determinations}

Plasma glucose was measured using a glucose analyzer (Beckman Instruments, Fullerton, California); data were expressed as mmol/1. The concentration of insulin or glucagon in plasma and pancreatic extracts was determined by radioimmunoassay. Insulin [21] and glucagon [22] were determined in tissue extracts using polyethylene glycol (Fisher Scientific, Pittsburg, Pennsylvania) to precipitate antigenantibody complexes. The concentrations of insulin [23] and glucagon [24] in plasma samples were determined using double antibody methods. Insulin assays were performed using monoiodinated insulin (New England Nuclear, North Billerica, Massachusetts), crystalline rat insulin standards ( $24 \mathrm{U} / \mathrm{ml}$, Novo, Bagsvaerd, Denmark), and guinea-pig anti-insulin (final dilution $1: 200000$, a gift from Dr. D. Porte,

\footnotetext{
1 Data from [13]
} 
Table 1. Changes in weekly body weights during the experimental period

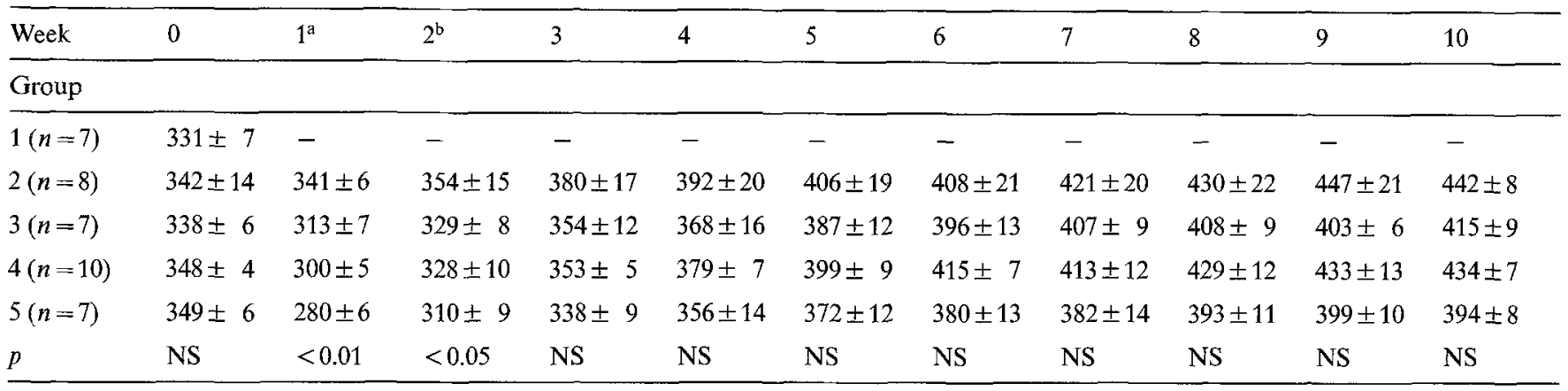

Data are mean \pm SEM. ${ }^{a} 2>3>4>5 p<0.01 ; 2^{b}, 3$ and $4>5, p<0.05$
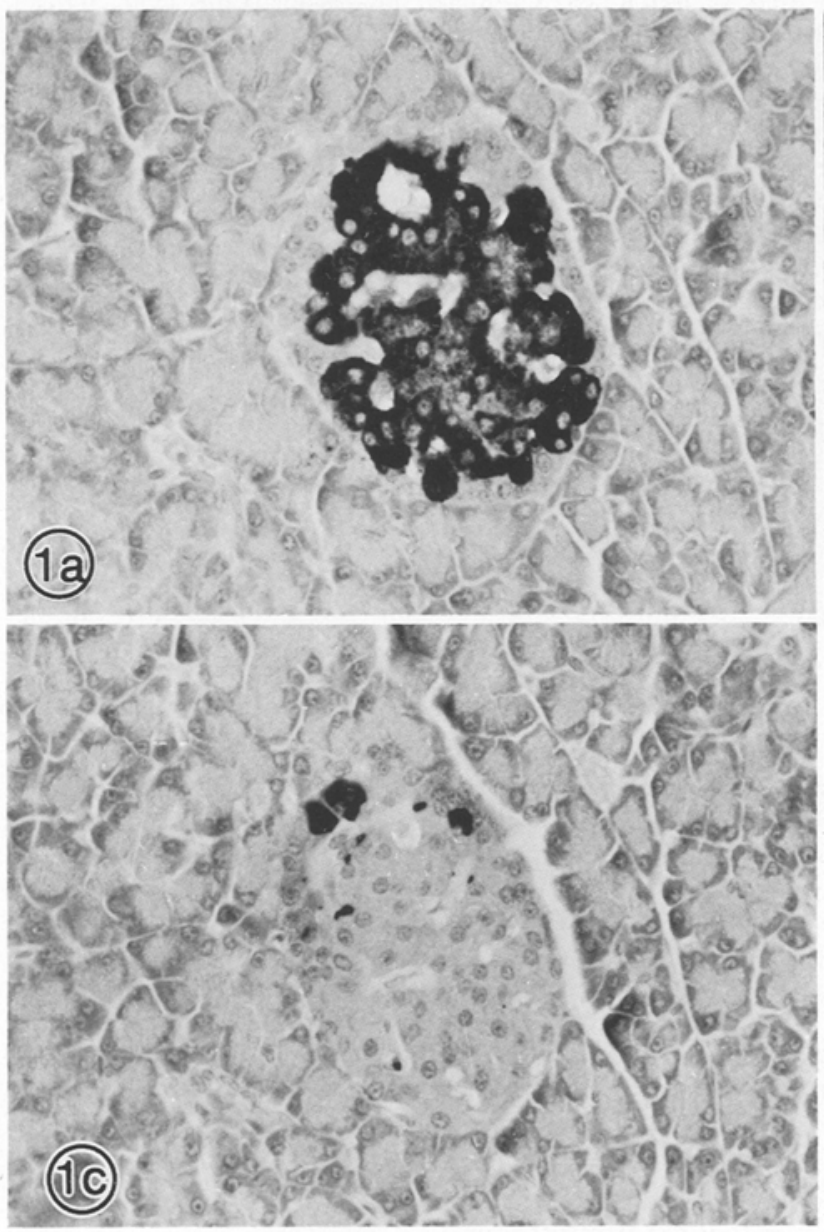

Jr., University of Washington, Seattle, Washington). Glucagon assays were performed using monoiodintaed glucagon (New England Nuclear), crystalline porcine glucagon standards $(50 \mathrm{ng} / \mathrm{ml}$, Novo), and the highly specific $[18,22]$ anti-pancreatic glucagon $14 \mathrm{D}$ (final dilution 1:5000). Sensitivities of the insulin and glucagon radioimmunoassays were $2 \mu \mathrm{U} / \mathrm{ml}$ and $25 \mathrm{pg} / \mathrm{ml}$, respectively. Interassay variability was $2 \%$ for the insulin assay and $10 \%$ for the glucagon assay. All assays were performed at $4{ }^{\circ} \mathrm{C}$ with appropriate aliquots of extracts or plasma diluted using $0.04 \mathrm{~mol} / 1$ phosphate-buffered saline $(\mathrm{pH} 7.6)$ containing $0.05 \%$ bovine serum albumin, $0.01 \mathrm{~mol} / 1$ benzamidine$\mathrm{HCl}$ and $0.05 \mathrm{~mol} / 1$ EDTA (all from Sigma). Duplicate samples $(0.5 \mathrm{ml})$ of appropriate dilutions were incubated with $0.3 \mathrm{ml}$ of the primary antibody and $0.3 \mathrm{ml}$ of the iodinated antigen. At the conclusion of the incubation times, second antibody (Antibodies Incorporated,

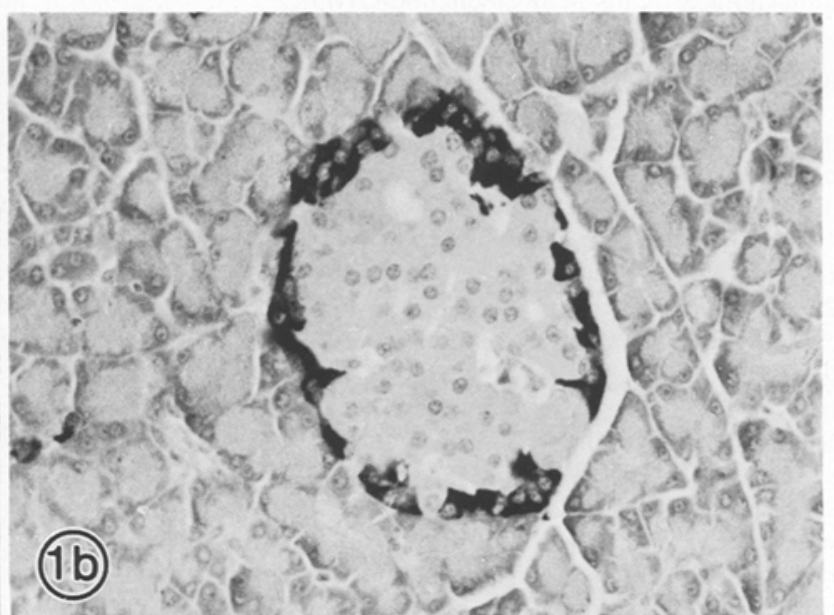

Fig. 1. Immunostained serial sections of a representative pancreatic islet from a rat in the pre-lesion group. a Central core of $\mathrm{B}$ cells stained black following incubation with anti-insulin. b A cells (black) at islet periphery stained by anti-glucagon. $\mathrm{c} D$ cells stained (black) following incubation with anti-somatostatin $(\times 300)$

Davis, California) or polyethylene glycol was added to the assay tubes. Following centrifugation ( $1500 \mathrm{~g}$ for $60 \mathrm{~min}$ at $4{ }^{\circ} \mathrm{C}$ ), the supernatant was decanted and the ratio of bound/total counts was determined using an autogamma counter (Beckman). Values obtained from the standard curves were multiplied by appropriate dilution factors and by pancreatic wet weight to calculate values for pancreatic hormone contents. The insulin:glucagon molar ratios were determined according to Unger [25].

\section{Statistical analyses}

All data are presented as mean \pm SEM. Comparisons were made using analysis of variance (ANOVA) followed by Newman-Keuls tests [26]; $p<0.05$ was considered significant. 

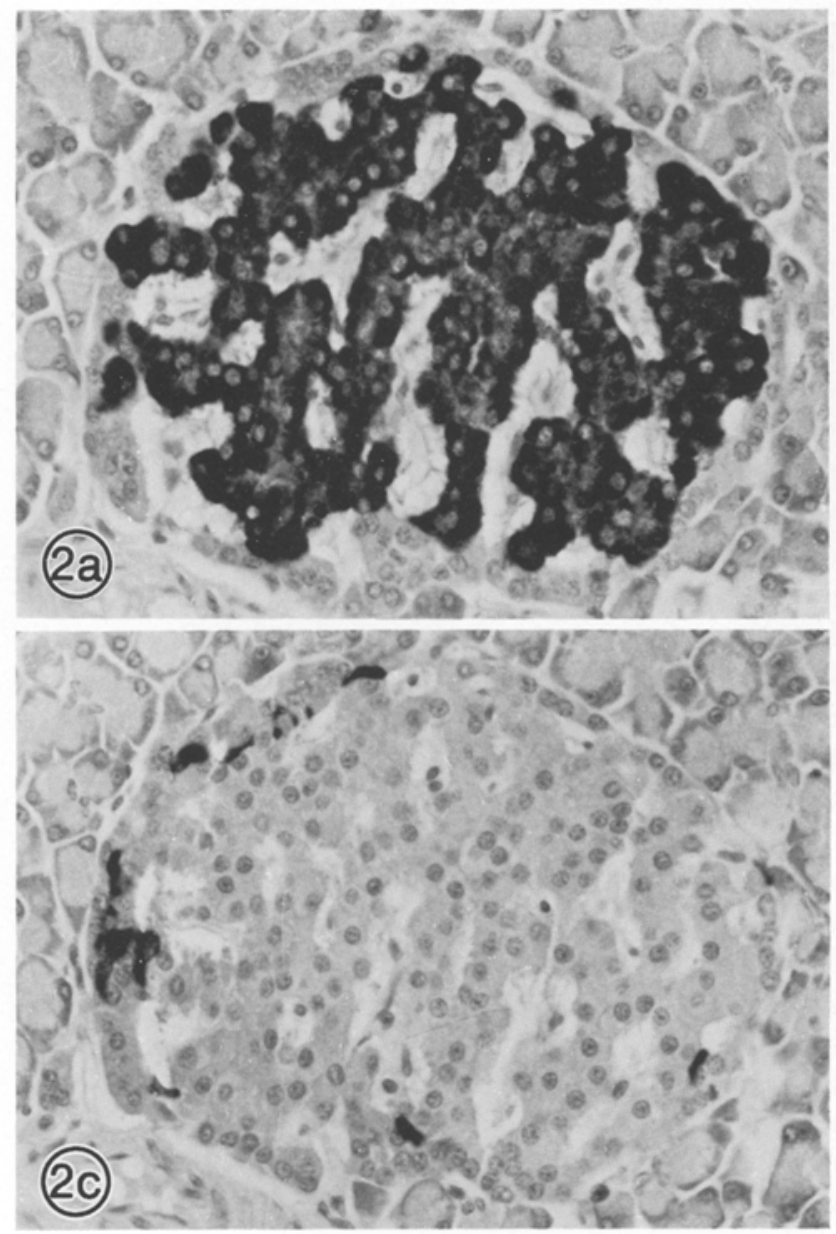

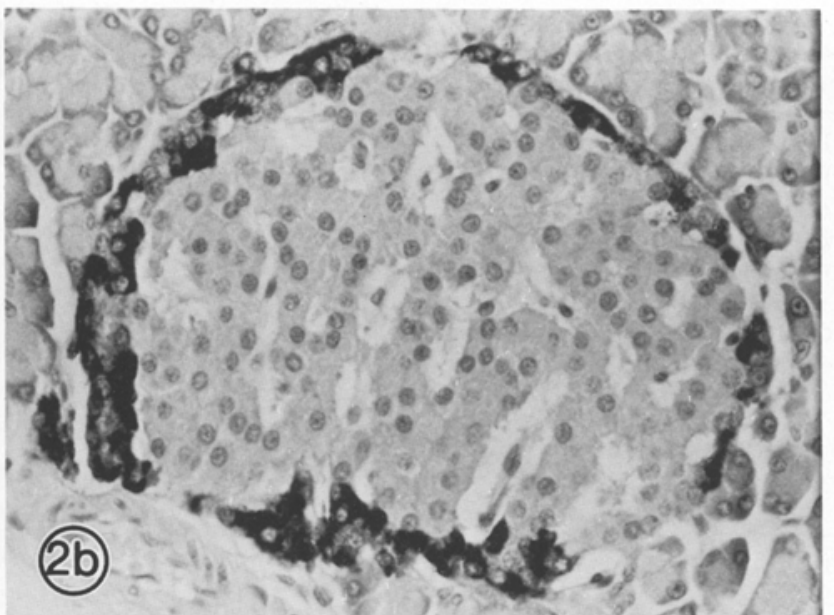

Fig. 2. Serial sections of an islet from a rat in the unoperated control group. a B cells stained black by anti-insulin. b Peripheral A cells immunostained with anti-glucagon. $\mathbf{c} \mathrm{D}$ cells at islet periphery (black) stained by anti-somatostatin. In both qualitative and quantitative [13] terms, islet of rats in the sham-lesioned group were similar to those shown here $(\times 300)$

\section{Results}

As reported in detail previously [13], fluorescence histochemical analyses revealed marked reductions in the number of dopamine-containing cells in the $\mathrm{SN}$ of rats given 6-OHDA lesions. When compared with unoperated controls (group 2) and sham-lesioned (group 3) animals, the low-dose (group 4) rats lost $65-80 \%$ and the high-dose (group 5) rats lost $80-95 \%$ of their respective nigral dopamine cells. The effects of SN lesions on body weight are presented in Table 1 . The mean body weights of all groups were comparable at the start of the experiment (week 0). At the end of the first week following surgery (week 1), the sham-operated (group 3), low-dose lesioned (group 4) and high-dose lesioned (group 5) rats showed significant reductions of body weight with respect to unoperated controls (group 2). By the end of the second week following surgery only the high-dose lesioned rats weighed significantly less than the other groups. There were no overall group differences of body weight from the third to the tenth week following surgery. Also, compared with pre-lesion (group 1) rats, there was a increase $(p<0.01)$ of body weight in groups $2-5$ over the 11-week experimental interval.

By examining adjacent immunostained sections (Figs.1 and 2), islet morphology and cytoarchitecture appeared qualitatively normal [18] in the pancreas of neurally intact rats (groups 1-3). Although many islets in the lesioned rats (groups 4 and 5) also appeared normal (13), those animals had a higher incidence of islets exhibiting degenerative changes, including degranulation, vacuolization, and connective tissue infiltration [27].

The quantitative effects of $\mathrm{SN}$ lesions on the volume densities of A, B, and D cells are summarized in Table 2 . There were significant overall group differences of Bcell volume density $\left(\mathrm{F}_{4,25}=4.64, p<0.01\right)$. Comparisons among group means revealed that B-cell volume density was less $(p<0.05)$ in the pancreas of pre-lesion, low-dose or high-dose lesioned rats when compared to that of animals in the unoperated control and sham-lesioned groups. More importantly, when the data from pre-lesioned rats were compared with that of the unoperated control and sham-lesioned animals, it was seen that an increase of B-cell volume density (approximately $60 \%$ ) occurred in the neurally-intact rats over the 11-week experimental period. There were, however, no comparable increases of B-cell volume density in the pancreas of lesioned rats during this interval. There 
Table 2. Volume density of specific types of islet cells in the pancreas

\begin{tabular}{llll}
\hline Experimental group & A-cells & B-cells & D-cells \\
\hline $1(n=7)$ & $0.19 \pm 0.03$ & $0.65 \pm 0.1^{\mathrm{a}}$ & $0.04 \pm 0.01$ \\
$2(n=8)$ & $0.25 \pm 0.04$ & $1.18 \pm 0.2$ & $0.04 \pm 0.01$ \\
$3(n=7)$ & $0.26 \pm 0.04$ & $1.1 \pm 0.2$ & $0.04 \pm 0.01$ \\
$4(n=10)$ & $0.19 \pm 0.04$ & $0.61 \pm 0.1^{\mathrm{a}}$ & $0.04 \pm 0.01$ \\
$5(n=7)$ & $0.25 \pm 0.06$ & $0.59 \pm 0.1^{\mathrm{a}}$ & $0.05 \pm 0.02$
\end{tabular}

Data are mean \pm SEM. ${ }^{a} p<0.05$ different from groups 2 and 3. Values are expressed as a percentage of total pancreatic tissue

Table 3. Relative percentages of A, B and D cells within the islets

\begin{tabular}{llll}
\hline Group & A cells & B cells & D cells \\
\hline $1(n=6)$ & $33 \pm 3^{\mathrm{a}}$ & $50 \pm 3^{\mathrm{a}}$ & $17 \pm 1^{\mathrm{a}}$ \\
$2(n=7)$ & $27 \pm 2$ & $59 \pm 3$ & $14 \pm 1$ \\
$3(n=6)$ & $25 \pm 1$ & $61 \pm 2$ & $14 \pm 1$ \\
$4(n=9)$ & $36 \pm 2^{\mathrm{a}}$ & $48 \pm 2^{\mathrm{a}}$ & $17 \pm 1^{\mathrm{a}}$ \\
$5(n=7)$ & $43 \pm 2^{\mathrm{a}}$ & $37 \pm 3^{\mathrm{a}}$ & $20 \pm 1^{\mathrm{a}}$ \\
$p$ & $<0.01$ & $<0.01$ & $<0.01$ \\
\hline
\end{tabular}

Data are mean \pm SEM. Values are based on at least 50 islets per pancreas. ${ }^{a} p<0.05$ different from groups 2 and 3

Table 4. Concentrations of insulin and glucagon extractable from the pancreas

\begin{tabular}{lllc}
\hline $\begin{array}{l}\text { Experimental } \\
\text { group }\end{array}$ & $\begin{array}{l}\text { Insulin } \\
\text { (mU/gland) }\end{array}$ & $\begin{array}{l}\text { Glucagon } \\
\text { (ng/gland) }\end{array}$ & $\begin{array}{l}\text { Insulin:glucagon } \\
\text { molar ratio }\end{array}$ \\
\hline $1(n=7)$ & $3.4 \pm 0.05^{\mathrm{a}}$ & $17.0 \pm 2.3$ & $4.8 \pm 0.9^{\mathrm{a}}$ \\
$2(n=8)$ & $6.1 \pm 0.05$ & $19.9 \pm 4.5$ & $9.2 \pm 1.6$ \\
$3(n=7)$ & $5.4 \pm 0.4$ & $17.4 \pm 3.3$ & $10.8 \pm 1.2$ \\
$4(n=10)$ & $5.1 \pm 0.5$ & $24.8 \pm 3.5$ & $5.9 \pm 1.0^{\mathrm{a}}$ \\
$5(n=7)$ & $4.4 \pm 0.4$ & $27.4 \pm 3.0$ & $3.5 \pm 0.3^{\mathrm{a}}$ \\
\hline
\end{tabular}

Data are mean \pm SEM. a $p<0.05$ different from groups 2 and 3

Table 5. Plasma levels of glucose, insulin, and glucagon

\begin{tabular}{lllll}
\hline $\begin{array}{l}\text { Experi- } \\
\text { mental } \\
\text { group }\end{array}$ & $\begin{array}{l}\text { Glucose } \\
(\mathrm{mM} / \mathrm{l})\end{array}$ & $\begin{array}{l}\text { Insulin } \\
(\mu \mathrm{U} / \mathrm{ml})\end{array}$ & $\begin{array}{l}\text { Glucagon } \\
(\mathrm{pg} / \mathrm{ml})\end{array}$ & $\begin{array}{l}\text { Insulin:glucagon } \\
\text { molar ratio }\end{array}$ \\
\hline $1(n=7)$ & $5 \pm 0.2$ & $54 \pm 7$ & $645 \pm 175$ & $1.3 \pm 0.2$ \\
$2(n=8)$ & $6 \pm 0.3$ & $54 \pm 7$ & $1165 \pm 254$ & $1.4 \pm 0.4$ \\
$3(n=7)$ & $5 \pm 0.3$ & $46 \pm 6$ & $1116 \pm 420$ & $1.4 \pm 0.5$ \\
$4(n=10)$ & $5 \pm 0.6$ & $62 \pm 5$ & $1175 \pm 310$ & $1.8 \pm 0.5$ \\
$5(n=7)$ & $6 \pm 0.2$ & $48 \pm 6$ & $1441 \pm 342$ & $1.2 \pm 0.3$ \\
\hline
\end{tabular}

Data are mean \pm SEM

were no significant alterations of A- or D-cell volume density between these groups during the experimental time period or following SN-lesioning.

The effects of $\mathrm{SN}$ lesions on the relative percentages of A, B and D cells within the islets are presented in Table 3. There were significant overall group differences in the percentages of all three islet cell types. Compared with the pre-lesion rats, (group 1), islets from older neurally intact rats (groups 2 and 3) showed an increase in the percentage of $B$ cells and a corresponding decrease in the percentage of $\mathrm{A}$ and $\mathrm{D}$ cells within the islets during the experimental period. However, islets from lesioned rats (groups 4 and 5) failed to show the increase in B cells and decreases in A and D cells during the experimental period.

The effects of SN lesions on the hormonal content of the pancreas are summarized in Table 4 . There were significant overall group differences of pancreatic insulin content $\left(\mathrm{F}_{4.34}=4.52, p<0.01\right)$. Compared with that of pre-lesion rats (group 1), the content of insulin in the pancreas of unoperated control (group 2) and sham-lesioned animals (group 3) increased approximately 70\% over the 11-week period $(p<0.05)$. In contrast to the unoperated control and sham lesioned groups, pancreatic insulin content in the lesioned groups (groups 4 and 5) was not significantly elevated above that of the prelesioned group. In terms of pancreatic content of glucagon, the lesioned animals tended to have higher levels than the other groups; however, those differences did not reach statistical significance. Nevertheless, the trend toward lower insulin and higher glucagon contents in the pancreas of $\mathrm{SN}$-lesioned rats was reflected by significant overall group differences of insulin: glucagon molar ratios $\left(F_{4.34}=3.07, p<0.05\right)$. When compared to the pre-lesion group, the older controls (groups 2 and 3 ) showed an age-related increase in the molar ratio of these two hormones. In contrast, the lesioned animals did not display an age-related increase in the molar ratio of insulin and glucagon. There were no significant differences between the five groups in terms of basal plasma levels of glucose, insulin, or glucagon, or the molar ratios of the circulating hormones (Table 5).

\section{Discussion}

Recently, we reported that SN lesions in rats were associated with reductions of both islet size and the percentage of pancreas occupied by islet tissue [13]. However, in our earlier study, we had not considered how potential alterations in the volume of specific endocrine cell populations might affect islet mass. In this study quantitative analyses, which assessed A, B, and D cells in SNlesioned rats, revealed that changes of islet volume density were primarily due to a reduction in B-cell volume density with respect to age-matched neurally intact rats. This phenomenon was interpreted as a decrease in the expected growth of B-cell mass rather than a disproportionate increase of exocrine tissue mass, because pancreatic weight was not changed as a result of SN lesions [13]. The lesion-associated decrease in B-cell growth was accompanied by alterations in local islet cytoarchitecture. Thus, the relative percentage of the different cell types within the islets changed from approximately $60 \% \mathrm{~B}$ cells, $26 \%$ A cells and $14 \% \mathrm{D}$ cells in older, neurally intact rats to $42 \%$ B cells, $40 \%$ A cells and $18 \% \mathrm{D}$ cells in lesioned rats. The significance of these local changes is not known, but they might be expected to result in changes in paracrine interactions within the islets. 
Although SN lesions apparently had no adverse effects upon basal hormone levels over the course of these experiments, an overview of the current data suggests a potential for longer-term metabolic consequences. Insulin content in the pancreas of lesioned rats was not markedly reduced despite decreased B-cell mass. This apparent paradox was not so surprising in view of studies showing that, in the pancreatectomized dog, systemic insulin levels were conserved despite an $80 \%$ reduction in pancreatic mass [28]. Moreover, in the rat, over $90 \%$ of the pancreas must be removed before overt signs of diabetes develop [29]. Thus, a $60 \%$ reduction in the total mass of $\mathrm{B}$ cells in the pancreas, as reported here, would not be expected to result in impaired function of the endocrine pancreas. Apparently, rats compensate for partial loss of B-cells via increased production and secretion of insulin by their remaining cells. But increased and continual requirement for insulin, in such cases, often promotes exhaustion and subsequent degeneration of the remaining B-cells [28]. Indeed, the classical signs of islet degeneration [27] we observed in $\mathrm{SN}$-lesioned rats seemed consistent with alterations caused by increased functional demands on the reduced B-cell population. The somewhat elevated levels of pancreatic and plasma glucagon (Tables 4 and 5) as well as the increase in the relative percentage of A-cells within the islets (Table 2 ) in lesioned animals also could be interpreted as a compensatory mechanism for the maintenance of B-cell function. That is, through well known paracrine interactions [30], an elevation of intraislet glucagon might have favoured an increase in the production and secretion of insulin. While the molar ratio of insulin: glucagon in plasma was comparable in all five groups, differences in the ratio of these hormones extractable from the pancreas of SN-lesioned rats might have led eventually to abnormalities of metabolic homeostasis.

The major question raised by this investigation relates to the mechanism through which SN lesions lead to a lack of growth of B cells. Because islet mass correlates with body weight [31], a decrease of B-cell volume density could have occurred as a result of weight loss, a factor commonly associated with $\mathrm{SN}$ lesions $[11,12]$. In this study, however, body weights of control and lesioned animals were comparable throughout most of the experiment because we utilized diet and feeding conditions that effectively prevent such differences [13]. It seems more likely that the failure of B-cell mass to increase in lesioned animals relates to a neurally regulated alteration of islet growth. It is amply documented that islet growth in rats continues throughout life, with B-cells making the major contribution [33]. Although our morphometric data in general compare favorably with those of previous studies concerning age-related changes in the rat endocrine pancreas, the increase of Bcell mass in neurally intact rats in the present study seems somewhat accelerated with respect to that reported by McEvoy [34]. This apparent discrepancy may be related to the diet and feeding schedules used in our experiments, since it is known that such a fasting-refeeding regimen stimulates B-cell secretion [35] and possibly B-cell growth was well. Because we established baseline conditions for islet mass through use of an agematched pre-lesion group (group 1), it was possible to determine that an increase of islet and B-cell mass occurred in neurally-intact animals (groups 2 and 3), but not in those given SN lesions (groups 4 and 5). The latter groups, in fact, were comparable to the much younger pre-lesion animals in terms of islet size and the volume density of individual endocrine cell types. Thus, it seems reasonable to conclude that islet growth is somewhat dependent upon the outflow of central autonomic signals.

The precise role of autonomic signals in regulating pancreatic islet morphology and growth has not been firmly established. Nevertheless, an intact nerve supply is vital for growth and development of other tissues, such as the parotid gland [36] or muscle [37]. Because islets are richly supplied with autonomic nerves $[1,2]$, it seems reasonable to speculate that innervation also plays an important role in promoting and/or maintaining their morphology. Support for this hypothesis can be found in reports showing that lesioning of the ventromedial hypothalamus not only increases islet function [7], but also stimulates islet growth [2,9]. Moreover, these phenomena seem dependent upon an intact nerve supply to the endocrine pancreas, since vagotomy [10] or islet transplantation [38] prevents both the morphological and functional sequelae of ventromedial hypothalamic lesioning.

Although certain regions of the central autonomic system have an impact upon islet structure and function $[1,2,10,31]$, the importance of the SN and many other central nervous system areas remain to be defined in this regard. Recent studies have suggested the existence of pathways between the $\mathrm{SN}$ and intermediolateral cells of the spinal cord [39], and between the $\mathrm{SN}$ and hypothalamic paraventricular nucleus [40]. Interestingly, the paraventricular nucleus has direct connections with the dorsal vagal complex [41]. Thus, the SN might play a role in modulating the outflow of both sympathetic and parasympathetic signals which ultimately reach the islets.

Acknowledgements. The authors wish to express their appreciation to M. Ryan and B. Toms for their excellent technical assistance. This investigation was supported, in part, by grants to Dr. P. H.Smith from the National Institute of Health (AM-25325) and the Hendricks Foundation of Upstate Medical Center, Syracuse, New York, USA.

\section{References}

1. Miller RE (1981) Pancreatic neuroendocrinology: peripheral neural mechanisms in the regulation of the islets of Langerhans. Endocrinol Rev 2: 471-494

2. Smith PH, Porte Jr D, Robertson RP (1979) Neural regulation of the endocrine pancreas. In: Pierluissi $J$ (ed) Endocrine pancreas 
and diabetes. International Congress Series 489, Excerpta Medica, Amsterdam, pp 64-95

3. Anand BK, Brobeck JR (1951) Hypothalamic control of food intake in rats and cats. Yale J Biol Med 24: 123-140

4. Brobeck JR, Tepperman J, Long CNH (1943) Hypothalamic hyperphagia in the albino rat. Yale J Biol Med 15: 47-53

5. Frohman LA, Bernardis LL (1971) Effect of hypothalamic stimulation on plasma glucose, insulin and glucagon levels. Am J Physiol 221: 1596-1603

6. Helman AM, Amira R, Nicolaidis S, Assan R (1980) Glucagon release induced by ventrolateral hypothalamic stimulation in the rat. Endocrinology 106: 1612-1619

7. Hustvedt BE, Løvø A (1972) Correlation between hyperinsulinemia and hyperphagia in rats with ventromedial hypothalamic lesions. Acta Physiol Scand 84: 29-33

8. Steffans AB, Mogenson GJ, Stevenson JAF (1972) Blood glucose, insulin and free fatty acids after stimulation and lesions of the hypothalamus. Am J Physiol 222: 1446-1452

9. Han PW, Yu YK, Chow ST (1970) Enlarged pancreatic islets of tube-fed hypophysectomized rats bearing hypothalamic lesions. Am J Physiol 218: 769-771

10. Powley TL, Opsahl CA (1976) Autonomic components of the feeding syndromes. In: Novin DA, Wyrwicka W, Bray GA (eds) Hunger, basic mechanisms and clinical implications. Raven Press, New York, pp 313-326

11. Marshall JF, Teitelbaum P(1973) A comparison of the eating in response to hypothermic and glucoprivic changes after nigral 6-hydroxydopamine and lateral hypothalamic electrolytic lesions in rats. Brain Res 55: 229-233

12. Ungerstedt $\mathbf{U}$ (1971) Stereotaxic mapping of the monoamine pathways in the rat brain. Acta Physiol Scand (Suppl) 367:1-48

13. Davis BJ, Smith PH (1984) Alterations of pancreatic islet size and growth following substantia nigra lesion in the rat. J Auton Nerv Syst 10: 167-180

14. Thoenen H, Tranzer JP (1968) Chemical sympathectomy by selective destruction of adrenergic nerves with 6-hydroxydopamine. Naunyn Schmiedebergs Arch Pharmacol Exp Pathol 261: 271-288

15. Breese GR, Traylor TD (1970) Effect of 6-hydroxydopamine on brain norepinephrine and dopamine: evidence for selective degeneration of catecholamine neurons. J Pharmacol Exp Ther 174: $413-420$

16. Pendleton RG, McCafferty JP, Roesler JM, Hieble JP (1978) Mechanism for gastric antisecretory effects of desmethylimipramine in rats. Eur J Pharmacol 75: 171-178

17. Baetens D, Malaisse-Lagae F, Perrelet A, Orci L (1979) Endocrine pancreas: three dimensional reconstruction shows two types of islets of Langerhans. Science 206: 1323-1325

18. Smith PH (1983) Immunocytochemical localization of glucagonlike and gastric inhibitory polypeptidelike peptides in the pancreatic islets and gastrointestinal tract. Am J Anat 168: 109-118

19. Elias H, Hyde D (1980) An elementary introduction to stereology (quantitative microscopy). Am J Anat 159: 412-446

20. Lazarow A, Carpenter AM (1962) Component quantitation of tissue sections I: characterization of the instruments. J Histochem Cytochem 10: 324-328

21. McEvoy RC, Hegre OD (1976) Fetal rat pancreas in organ culture. Effects of media supplementation with various steroid hormones on the acinar and islet components. Differentiation 6: 105-111

22. McEvoy RC, Madson KL, Elde RP (1977) Stimulation of antiglucagon antibodies in rabbits. Horm Metab Res 9: 272-274

23. Morgan CR, Lazarow A (1963) Immunoassay of insulin: two antibody systems. Diabetes 12: 115-126
24. Hazzard WR, Crockford PM, Buchanan KD, Vance JE, Cohen R, Williams RH (1968) A double antibody immunoassay for glucagon. Diabetes 17: 179-186

25. Unger RH (1972) Insulin/glucagon ratio. Isr J Med Sci 8: 252-257

26. Winer BJ (1962) Statistical principles in experimental design. McGraw Hill, New York

27. Hadju A, Rona B (1967) Morphological observations on spontaneous islet changes in rats. Diabetes 16: 108-110

28. Marincola F, Cobb LF, Horaguchi A, Maeda M, Merrell R (1984) Accomodation to a reduced islet cell mass in dogs. Am J Physiology $247:$ E456-461

29. Logothetopoulos $J$ (1972) Islet regeneration and neogenesis. In: Steiner DF, Freinkel NT (eds) Handbook of physiology, Section 7, Vol 1, Endocrine pancreas. American Physiological Society, Baltimore, pp 67-76

30. Orci L (1982) Macro- and microdomains in the endocrine pancreas. Diabetes 31: 538-565

31. Woods SC, Porte Jr D (1978) The central nervous system, pancreatic hormones, feeding and obesity. Adv Metab Disord 9:282-312

32. Hellman B, Peterson B, Hellerström C (1970) The growth pattern of the endocrine pancreas in mammals. In: Falkmer S, Hellman B, Taljedal I-B (eds) The structure and metabolism of the pancreatic islets. Pergammon, Oxford, pp 45-67

33. Hellman B (1959) The total volume of the pancreatic islet tissue at different ages of the rat. Acta Pathol Microbiol Immunol Scand 47: $35-50$

34. McEvoy RC (1981) Changes in the volumes of A-, B-, and D-cell populations in the pancreatic islets during the postnatal development of the rat. Diabetes $30: 813-817$

35. Ip MM, Ip C, Tepperman HM, Tepperman J (1977) Effect of adaptation to meal-feeding on insulin, glucagon and the cyclic nucleotide-protein kinase system in rats. J Nutr 107: 746-757

36. Bloom G, Carslöö B, Danielsson A, Hellström S, Henriksson R (1981) Trophic effect of sympathetic nervous system on the early development of the rat parotid gland: a quantitative ultrastructural study. Anat Rec 201:645-654

37. Dennis MJ (1981) Development of the neuromuscular junction: inductive interactions between cells. Annu Rev Neurosci 4: 43-68

38. Inoue S, Bray GA, Mullen YS (1978) Transplantation of pancreatic B cells prevents development of hypothalamic obesity in rats. Am J Physiol 235: E266-E271

39. Skagerborg G, Björklund A, Lindvall O, Schmidt R (1982) Origin and termination of the diecephalo-spinal dopamine system in the rat. Brain Res Bull 9:237-244

40. Wright AK, Tulloch IF, Arbuthnott GW (1980) Possible links between hypothalamus and substantia nigra in the rat. Appetite 1: 43-51.

41. Swanson LW, Sawchenko PE (1980) Paraventricular nucleus: a site for the integration of neuroendocrine and autonomic mechanisms. Neuroendocrinology $31: 410-417$

Received: 11 February 1985

and in revised form: 12 August 1985

Dr. Barbara J. Davis

Department of Neurology, Box 673

University of Rochester School of Medicine and Dentistry

601 Elmwood Avenue

Rochester, NY 14642

USA 